\title{
Research on Public English Teaching Reform in Higher Vocational Colleges Based on the Combination of Work and Study
}

\author{
Liyu Liu \\ Sichuan Aerospace Vocational College \\ 610000
}

Keywords: Combination of Work and Study; Higher Vocational Education; Public English; Reform

\begin{abstract}
The application of the concept of work-study combination in higher vocational education can help such schools and related teachers effectively achieves the goal of talent training in higher vocational education. This article first analyzes the problems still existing in the current stage of public English teaching in higher vocational colleges, and on this basis, studies the reform methods of public English teaching in vocational colleges through the combination of work and study.
\end{abstract}

\section{Introduction}

With the continuous development of China's education system, all kinds of new teaching concepts and teaching methods have been more widely used in this process. For the issues discussed in this paper, higher vocational schools are the first line of skills to the society. The main approach of talents, therefore, in the actual teaching process of higher vocational public English teachers should avoid only use the vocabulary, grammar and other theoretical content to explain the situation, the English teaching content should be effectively combined with the student professional to ensure that students use it out after the job can effectively apply the English teaching content. For this kind of requirement, there are certain flaws in most of the higher vocational public English teaching systems in China. This article will first analyze these issues and study the method of public English teaching reform in higher vocational education under the combination of work and study.

\section{Problems Still Existing in Vocational English Teaching At Present Stage}

\subsection{Teaching Goals Do Not Match Market Demand}

According to the current situation, most higher vocational schools have the phenomenon of taking passing the English application ability test for colleges and universities as a goal of public English teaching. However, for the requirements of employers for higher vocational graduates, such teaching goals will lead to the following problems arising: 1. The student's English application ability is difficult to guarantee [1]. Under the influence of the above-mentioned teaching objectives, most of the higher vocational schools assess the quality of teaching and the level of English of the students through test scores. In this context, students may be able to acquire some knowledge of English, but for a long time the exam-oriented education will inevitably lead vocational students to apply the content learned in the classroom to the actual work process. Employers require that vocational students should be able to work as first-line skilled talents, and restrictions on English application ability will inevitably lead to students being affected during job hunting or employment. 2.Students are unable to deal with professional English content. Compared with the rapid development of the market, the scope of the examination is relatively fixed, and if the teacher can only combine the content of the exam to start English teaching, then the students' mastery of professional English content is bound to meet the needs of the employer. The requirements for vocational students' practical ability in the market are very high. Most employers will examine students' professional English mastery during the recruitment process, and overly fixed teaching objectives inevitably lead to students being hindered in the job hunting process.

\subsection{Teaching Content Lags Behind Market Development}

For higher vocational students, this part of the students has already contacted and learned most of the grammar, vocabulary and other knowledge in the middle school. In the process of teaching 
public English in higher vocational education, most of the teaching materials are still compiled with these contents as the main body. In this context, students are not exposed to new content in the classroom and their interest in English learning will be reduced accordingly. On the other hand, as mentioned above, after graduating from a vocational college, students should be able to enter the first-line skilled positions to start work. In this type of position, a large number of new ideas and techniques need to be applied in practical work if the students are in English. Mastering content limited to textbooks, the development of specific jobs is bound to be affected.

\subsection{Old Teaching Methods}

English teaching mainly aims at cultivating students' abilities in listening, speaking, reading and writing, and improving students' English literacy. For such requirements, most higher vocational English teachers still use traditional teaching methods. Students' participation in the class and their enthusiasm for learning are difficult to effectively improve, and the effectiveness of public English teaching in higher vocational education is naturally difficult to guarantee [2]. For example, some higher vocational English teachers are still using the traditional "cramming" method of teaching. In the classroom, they focus on a large amount of theoretical content. They do not give students enough time to think and practice. Students can only passively accept it. The contents are explained by teachers, under such a model, students' interest in English courses will inevitably show a certain downward trend. It is difficult to achieve the goal of improving English literacy for higher vocational students through English teaching.

\section{Public English Teaching Reform in Higher Vocational Colleges Based on Combination of Work and Study}

\subsection{Promote the Combination of English Teaching Content and English in the Industry}

Combined with the above, higher vocational students must be able to acquire a certain level of professional English ability based on the mastery of basic English skills. For such requirements, higher vocational schools should improve public English teaching content and industry through the following points. The effective combination of English: 1.Combining different professional characteristics to develop different teaching programs. The difference between the contents of English in different industries is very large. For example, for students majoring in electronics, these students should be able to effectively grasp English content related to components and electronic measuring instruments, and financial Professional students should effectively grasp the relevant English content in the course of economic activities. Combined with these contents, vocational English teachers can set different teaching programs for different majors. Taking the teaching of tourism students as an example, teachers can introduce appropriate tourism-related English content in the teaching process, and combine the development of the tourism industry to make changes to the content of the teaching, so as to achieve the goal of improving the professional English ability of higher vocational students. 2. According to professional assessment [3]. As mentioned above, the difference between the English content of different professions involved in the industry is very large. Therefore, in the process of assessment, higher vocational schools should avoid the general situation and set different inspection contents for different professions. To ensure that English based teaching content and professional English content can be considered at the same time. For example, higher vocational schools can increase their speaking test for tourism, marketing, and other specialties on the basis of the original, and increase the reading ability of professional books or papers for electronic and computer majors. Under such a model, students naturally have a focus in the learning process, and then better meet the needs of employers in the job search process.

\subsection{Organize Open Education Under the Combination of Work and Study}

The traditional teaching model is mainly carried out between teachers and students. Although students can learn and master some English skills in the classroom, for practical work, an overly closed teaching model will still make it difficult for students to enter a job. Adaptation can not be 
applied to work in the classroom. In response to such problems, higher vocational schools should implement open-running schools from the following aspects through the application of the concept of a combination of work and study: 1.Input. Higher vocational schools can invite front-line positions. Work-experienced employees can use the forms of lectures and experience sharing to help students understand the current requirements for professional English proficiency in the market. Through the holding of such activities, higher vocational students will be able to better understand the importance of English learning and be able to better target the learning process. 2. Output. Higher vocational schools should allow students to participate in practical work through practical training methods under the conditions permitting, and to feel the importance of English skills in this process. Through the combination of practical training mode and teaching process, students will have a preliminary grasp of the actual work environment and will naturally be able to better understand what kind of requirements a particular job requires for English language skills, and then to improve one's English literacy by searching for missing information in the learning process.

\subsection{Reform Higher Vocational English Teaching Methods}

From the perspective of work-study combination, the reform of higher vocational public English teaching methods should start from the following aspects: 1. Using modern teaching methods to carry out teaching [4]. Through the application of multimedia, internet and other means, the interest in the English class will be greatly improved. At the same time, English teachers will be able to more quickly understand and grasp the development of related industry markets, and based on these contents, the existing teaching programs Make improvements. 2. Flexible application of new teaching methods. The use of situational pedagogy and inquiry pedagogy can all improve students' participation and teaching effectiveness on the basis of the original. Therefore, the public English teachers in higher vocational schools should flexibly select teaching methods on the basis of inspecting student characteristics to ensure that students Can actively participate in the English teaching process.

\section{Conclusion}

In summary, based on the analysis of the problems still existing in the English teaching process of higher vocational schools in China, this paper mainly promotes the combination of public English teaching content and English in the industry, and organizes open education in the combination of work and study. The reform of vocational English teaching methods in three aspects of higher vocational public English teaching reform methods are described. In general, higher vocational schools and higher vocational English teachers should make full use of market development and student characteristics to make improvements in teaching programs and teaching methods to ensure that graduates of higher vocational schools can meet employers' requirements.

\section{References:}

[1] Li Shuping. Observing the Construction of Public English Courses in Higher Vocational Education from the Combination of Work and Study [J]. Liaoning Higher Vocational Technical Journal, 2010, (6).

[2] Wu Yanping, Ma Yurong, Li Yongcai. A Study of the Combination of Work and Study in Higher Vocational Public English Teaching Reform [J]. Value Engineering, 2014, (2).

[3] Fan Yanping. Exploration of Higher Vocational Public English Teaching Model Based on the Combination of Work and Study [J]. Education and Occupation, 2013, (20).

[4] Wang Xueyan. Construction of the Public English Teaching Staff in Higher Vocational Education under the Combination of Work and Study [J]. Education and Occupation, 2012, (9). 